\title{
Heats of Combustion of Leaf Proteins, and Incidentally of Linseed Mucilage and Gitrus Pectin
}

\author{
By J. W. H. LUGG and P. STANLEY \\ Department of Biochemistry, University of Melbourne, Melbourne, Victoria
}

(Received ro November 1947)

In computing the energy metabolism of animals on various diets it is commonly assumed that the catabolized protein would yield $5 \cdot 7 \mathrm{Cal} . \% / \mathrm{g}$. if burned in such a way that the elements would yield $\mathrm{CO}_{2}$, water, $\mathrm{H}_{2} \mathrm{SO}_{4}$ and nitrogen. This value is based upon the heats of combustion of several proteins of animal origin and numerous proteins obtained from plant seeds. Due allowance must be made for the fact that much of the protein $\mathrm{N}$ will ordinarily appear after catabolism as urea $\mathrm{N}$, and hence the net calorific value to the animal is less than that found by oxidation in a bomb or oxycalorimeter.

The precision attainable in animal metabolism studies is quite high with modern equipment, but interpretation of the data is often rendered less certain than it should be by lack of information about the heats of combustion of the particular proteins involved in the metabolism. This is particularly true for diets containing much pasture protein, as the literature provides no information about the heats of combustion of these proteins.

This article reports a study of the heats of combustion of four leaf-protein preparations, which were unavoidably contaminated with impurities. It was accordingly necessary to estimate the amounts of impurities present, and their contributions to the heats of combustion. From these data the heats of combustion of the hypothetically 'pure' proteins have been computed. Although allowance has been made for the contribution of these contaminants to the total heat production, the precise nature of the major contaminants in preparations of this kind is unknown. The question has been reviewed by Lugg (1939), who considered that they were probably of the nature of mucilage or pectin.

\section{The protein preparations}

\section{EXPERIMENTAL}

These were the preparations described by Lugg \& Weller (1944). Information concerning them is given in Table $\mathrm{x}$. Of the nitrogen present in these preparations about $36 \%$ in each case has been accounted for as amide or specific amino-acid in the analyses thus far completed.

\section{The linseed-mucilage and citrus-pectin preparations}

A purified pectin ('pectinic acid') was made from a commercial citrus pectin ('pectin material') by dissolving it at about $40^{\circ}$ in a solution containing $5 \mathrm{~g} . / \mathrm{l}$ ammonium oxalate, centrifuging the viscous solution at $2000 \times \mathrm{g}$ for $\mathrm{I}$ hr., treating the

- The symbol 'Cal.' represents $100015^{\circ}$ gram-calories. 
viscous centrifugate with 2 vol. ethanol containing a little $\mathrm{HCl}$ and separating the gelatinous precipitate by squeezing in fine-meshed cloth. The precipitate was washed several times with $60 \%$ (by weight) ethanol-water solution acidified to $0.0005 \mathrm{~N}$ with $\mathrm{HCl}$, and then with absolute ethanol. The residue was dried in the air and then for $8 \mathrm{hr}$. at $85^{\circ}$. It was then powdered and allowed to come to equilibrium with air moisture.

Table 1. Analytical data concerning the leaf-protein, linseed-mucilage and citrus-pectin preparations

\begin{tabular}{|c|c|c|c|c|c|c|c|c|}
\hline \multirow[b]{2}{*}{ Preparation } & \multicolumn{6}{|c|}{ 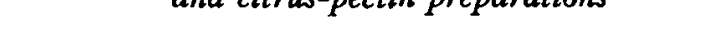 } & \multirow[b]{2}{*}{$\begin{array}{c}\text { Calculated } \\
\text { contami- } \\
\text { nation by } \\
\text { ash } \\
\text { constituents } \\
(\%)\end{array}$} & \multirow[b]{2}{*}{$\begin{array}{c}\text { Calculated } \\
\text { contami- } \\
\text { nation by } \\
\text { other } \\
\text { materials } \\
(\%)\end{array}$} \\
\hline & $\begin{array}{l}N^{*} \\
(\%)\end{array}$ & $\begin{array}{c}\mathrm{S} \\
(\%)\end{array}$ & $\begin{array}{c}\text { Ash } \\
(\%)\end{array}$ & $\begin{array}{l}\text { Approx. } \\
\text { amount of } \\
\mathrm{SiO}_{2} \text { in } \\
\text { ash } \\
(\%)\end{array}$ & $\begin{array}{l}\text { Approx. } \\
\text { amount of } \\
\mathrm{Ca} \text { in } \\
\text { ash } \\
(\%)\end{array}$ & $\begin{array}{l}\mathrm{N} \text { in hypo- } \\
\text { thetically } \\
\text { pure } \\
\text { preparation } \\
(\%)\end{array}$ & & \\
\hline \multicolumn{9}{|l|}{ Leaf protein: } \\
\hline $\begin{array}{l}\text { IE† (Phalaris tuberosa) } \\
2 \mathrm{E} \dagger \text { (Hordeum murimum) } \\
\text { 3E† (Medicago sativa) } \\
4 \mathrm{E} \dagger \text { (M. denticulata) }\end{array}$ & $\begin{array}{l}14 \cdot 90 \\
14 \cdot 10 \\
14.15 \\
14.55\end{array}$ & $\begin{array}{l}1.13 \\
0.98 \\
0.87 \\
0.92\end{array}$ & $\begin{array}{l}1 \cdot 8 \\
2 \cdot 3 \\
2 \cdot 8 \\
1 \cdot 4\end{array}$ & $\begin{array}{l}20 \\
30 \\
30 \\
40\end{array}$ & $\begin{array}{l}20 \\
20 \\
20 \\
20\end{array}$ & $\begin{array}{l}16 \cdot 4 \\
16 \cdot 4 \\
16 \cdot 4 \\
16 \cdot 4\end{array}$ & $\begin{array}{l}0.9 \\
1 \cdot 2 \\
1 \cdot 5 \\
0.8\end{array}$ & $\begin{array}{r}8 \cdot 2 \\
12 \cdot 9 \\
12 \cdot 2 \\
10 \cdot 5\end{array}$ \\
\hline Linseed mucilage: & 0.31 & Trace & $5 \cdot 8$ & 20 & 10 & 0.0 & 4.9 & 0.4 \\
\hline Citrus pectin: & 0.40 & Trace & $=1 \cdot 0$ & 20 & 40 & 0.0 & 0.6 & 0.5 \\
\hline
\end{tabular}

A sample of linseed mucilage was prepared from entire linseeds. The rapidly washed seeds were allowed to stand with water (with occasional stirring) at $20^{\circ}$ for $24 \mathrm{hr}$. The highly viscous liquid, separated from the seeds by squeezing in a coarse-meshed cloth, was treated with ammonium oxalate to a concentration of $5 \mathrm{~g} . / 1$. and centrifuged at $2000 \times g$ for $\mathrm{I} \mathrm{hr}$., and the centrifugate was then treated as in the preparation of the pectin.

Nitrogen estimations were made by the Kjeldahl method.

\section{The inorganic impurities in the preparations}

The ash content was estimated by igniting samples of the materials in air at about $600^{\circ}$. The $\mathrm{SiO}_{2}$ contents of ash samples were estimated by first digesting the ash with $\mathrm{H}_{2} \mathrm{SO}_{4}$ and again igniting, then reweighing and determining the loss in weight after digestion with $\mathrm{HF}$ and $\mathrm{H}_{2} \mathrm{SO}_{4}$ and further ignition. $\mathrm{Ca}$ contents of ash samples were estimated by precipitating the $\mathrm{Ca}$ as oxalate from $\mathrm{HCl}$ extracts of the ash, first adjusted to $\mathrm{pH} 5.7$ with ammonia. The estimates of $\mathrm{SiO}_{2}$ and of $\mathrm{Ca}$ could be regarded as approximate only, and rounded off values are given in Table $\mathrm{I}$.

The assumption has been made that in the original preparations the $\mathrm{Ca}$ had replaced ionizable $\mathrm{H}$ of the carboxyl groups. In computing the contributions of $\mathrm{Ca}$ compounds to the ash it has been assumed further that in the mucilage and pectin 
ash the $\mathrm{Ca}$ must have been present chiefly as $\mathrm{CaCO}_{3}$, and in that of the leaf-protein preparations, largely as $\mathrm{CaSO}_{4}$. This assumption, drawn from the known circumstances, was substantiated by qualitative tests. Remaining substances in the ash $\left(\mathrm{Al}_{2} \mathrm{O}_{3}\right.$ ? etc.) were presumed (like $\left.\mathrm{SiO}_{2}\right)$ to have been present as such in the original preparations.

The computed percentage contaminations of the preparations by inorganic impurities are shown in Table $\mathbf{I}$.

\section{The organic impurities in the preparations}

Depending upon the method of preparation, samples of protein from leaf tissue may possess distinctly different $\mathrm{N}$ contents and yet be of apparently the same, or very similar, amide and amino-acid composition when the values are reported on a $\mathrm{N}$ basis. The assumption has been made (Lugg, 1939) that such preparations contain no, or virtually no, prosthetically bound polysaccharide or polyuronide; and from its behaviour under conditions of acid hydrolysis, it has been considered that the major organic contaminant may be pentosan, pectin, or mucilage. More detailed considerations (Lugg, 1939) have led to the conclusion that this contaminant is probably mucilage or pectin, and perhaps more probably the former.

The amino-acid compositions of the leaf proteins suggested that the $\mathrm{N}$ content of the pure proteins would be approximately $16.5 \%$ (Lugg, 1939). This value has not been affected appreciably by subsequent information concerning the amino-acid compositions (e.g. Lugg \& Weller, 1948). Examination and comparison of the acid humins formed during the acid hydrolysis of impure preparations from Dactylis glomerat $a$ and of edestin mixed with L-arabinose suggested that the preparations would contain approximately $16.75 \% \mathrm{~N}$ if the contaminant were a pentosan (Lugg, 1939). In the current work, comparisons have been made of the acid humins formed during the acid hydrolysis of preparations $\mathrm{IE}, 2 \mathrm{E}, 3 \mathrm{E}$ and $4 \mathrm{E}$ of Lugg \& Weller (1944) and of edestin mixed with mucilage and with pectin. They suggest that the pure preparations may differ somewhat in $\mathrm{N}$ content ( $16 \cdot 1-16.7 \%$, mean $16.3 \%$ ) if the contaminant is a mixture of equal parts of mucilage and pectin. Incidentally, the pectin was found to yield about $80 \%$ as much humin with edestin as did the mucilage.

As the precise natures of the contaminants are uncertain, and as the leaf proteins are not of the same composition as edestin, some weight must be given to the value ( $16.5 \%$ ) for the $\mathrm{N}$ content of the pure leaf proteins derived from a consideration of amino-acid composition. For the purposes of subsequent calculations of the heats of combustion, it has been assumed that the four preparations would have contained $16.4 \% \mathrm{~N}$ if pure, and that the contaminant in each case consisted of a mixture of equal parts of pure mucilage and pectin.

The $\mathrm{N}$ in the mucilage and pectin preparations was found to occur almost entirely in the form of bound $\mathrm{NH}_{3}$, presumably as ammonium salts of the uronic acid residues.

The percentage contaminations of the preparations by the organic impurities are shown in Table $\mathrm{I}$. 


\section{Determination of heats of combustion}

Compressed tablets of the powdered, air-dry materials were burned in an oxygen bomb calorimeter, the dry weights of the tablets being computed from the moisture contents of the materials, estimated independently by drying samples at $105^{\circ}$ for $8 \mathrm{hr}$. and then in vacuo over $\mathrm{H}_{2} \mathrm{SO}_{4}$ for $18 \mathrm{hr}$. at $20^{\circ}$.

The bomb calorimeter was of standard Berthelot-Mahler-Kröker type, combustions being carried out in oxygen at $27 \mathrm{~atm}$. pressure (Lunge \& Berl, 1921). Ignition was effected by electrical heating of a fine nickel wire. Temperature rises, arranged to amount to about $3^{\circ}$, were measured with a Beckmann thermometer. Corrections for temperature gradients were calculated from the Regnault-Pfaundler formula.

Table 2. The heats of combustion of the leaf-protein, linseed-mucilage and citrus-pectin preparations

\begin{tabular}{|c|c|c|c|c|c|c|}
\hline \multirow[b]{3}{*}{ Individual results (Cal./g.) } & \multicolumn{4}{|c|}{ Leaf protein } & \multirow{2}{*}{$\begin{array}{l}\text { Linseed } \\
\text { mucilage }\end{array}$} & \multirow{2}{*}{$\begin{array}{l}\text { Citrus } \\
\text { pectin }\end{array}$} \\
\hline & $I E^{*}$ & $2 E^{\star}$ & $3 E *$ & ${ }_{4} E^{*}$ & & \\
\hline & $\begin{array}{l}5.63 \mathrm{r} \\
5.634 \\
5.621\end{array}$ & $\begin{array}{l}5.557 \\
5.559 \\
-\end{array}$ & $\begin{array}{l}5.558 \\
5.560 \\
-\end{array}$ & $\begin{array}{l}5.642 \\
5.638 \\
5.652\end{array}$ & $\begin{array}{l}3 \cdot 892 \\
3 \cdot 901 \\
3 \cdot 910\end{array}$ & $\begin{array}{c}3.702 \\
3.698 \\
-\end{array}$ \\
\hline Mean values (Cal./g.) & 5.629 & 5.558 & 5.559 & $5 \cdot 644$ & 3.901 & 3.700 \\
\hline $\begin{array}{l}\text { Values for pure substances } \\
\text { (Cal./g.) }\end{array}$ & $5^{\cdot 839}$ & $\begin{array}{r}5.882 \\
-5 e e\end{array}$ & $5 \cdot 888$ & $5 \cdot 899$ & $4 \cdot 101$ & $37 \times 9$ \\
\hline
\end{tabular}

The water equivalent of the bomb-calorimeter assembly was determined by burning samples of pure benzoic acid previously dried by exposure over $\mathrm{P}_{\mathbf{8}} \mathrm{O}_{5}$ at $20^{\circ}$ for long periods. Its heat of combustion was taken to be 6.3133 Cal./g. (Jessup \& Green, 1934).

Acids formed during the combustions were collected in $10 \mathrm{ml}$. water and, after removal of $\mathrm{CO}_{2}$, estimated by titration. The $\mathrm{H}_{2} \mathrm{SO}_{4}$ formed was estimated gravimetrically as $\mathrm{BaSO}_{4}$ and deducted from the total acidity, to yield a quantity attributed to $\mathrm{HNO}_{3}$ produced by combustion of $\mathrm{N}$. This quantity was small ( $\mathrm{I}-2 \mathrm{ml}$. of $0.1 \mathrm{~N}$ acid) in the standardization combustions of benzoic acid $\left(\mathrm{H}_{2} \mathrm{SO}_{4}\right.$ was then absent) and was probably due to traces of nitrogen in the oxygen used. It was small, too, when mucilage and pectin were, burned, but relatively large (10-12 $\mathrm{ml} .0 .1 \mathrm{~N}$ acid) when protein preparations were burned. The correction for the formation of $\mathrm{HNO}_{3}$ was taken to be $-14.3 \mathrm{Cal} . / \mathrm{mol}$.

It was found that in every instance almost all the ash was retained in the combustion crucible.

\section{RESULTS}

The individual and mean values for the heats of combustion/g. of dry preparation (corrected for $\mathrm{HNO}_{3}$ formation and nickel-wire combustion) are shown in Table 2. They correspond to the formation of $\mathrm{CO}_{2}$ and water and, with protein preparations, of dilute $\mathrm{H}_{2} \mathrm{SO}_{4}$ and nitrogen at $27 \mathrm{~atm}$. and at an average temperature of $20^{\circ}$, but additional reactions (e.g. formation of $\mathrm{CaCO}_{3}$ and $\mathrm{CaSO}_{4}$ ) have also taken place.

The mean values for mucilage and pectin have been corrected in the following manner. For the $\mathrm{Ca}$ in the preparations, $5 \mathrm{Cal} / 4^{\circ} \mathrm{g}$. of $\mathrm{Ca}$ have been subtracted. This 
represents the difference between heats of combustion of $4 \circ \mathrm{g}$. Ca and $2 \mathrm{~g}$. hydrogen in their standard states, plus the heat of formation of $\mathrm{CaCO}_{3}$ from $\mathrm{CaO}$ and $\mathrm{CO}_{2}$, minus the difference in the heats of formation of $\mathrm{Ca}$ salts and carboxylic acids (mean for formic, acetic, glycollic acids). For the $\mathrm{N}$ in the preparations $7 \times \cdot 2$ Cal./14 g. (based on the heat of dissociation of $\mathrm{NH}_{3}$ from ammonium acetate and the heat of combustion of $\mathrm{NH}_{3}$ to nitrogen and water) have been deducted. The net heats of combustion have been corrected to give values/g. of pure material (last row of Table 2).

The mean values for the leaf-protein preparations have been corrected as follows. For the $\mathrm{Ca}$ in the preparations $6.4 \mathrm{Cal} / \mathrm{4}$ \% $\mathrm{g}$. have been deducted, representing the difference between the heats of combustion of $\mathrm{Ca}$ and hydrogen, plus the difference between the heat of formation of $\mathrm{CaSO}_{4}$ from $\mathrm{CaO}$ and $\mathrm{SO}_{3}$ and that of the formation of dilute $\mathrm{H}_{2} \mathrm{SO}_{4}$ from the same amount of $\mathrm{SO}_{3}$, minus the difference in the heats of formation of $\mathrm{Ca}$ salts and carboxylic acids. For the other contaminants, 3.91 Cal./g. (mean of heats of combustion of pure mucilage and pectin) have been deducted. The net heats of combustion have been corrected to give values/g. of pure protein (last row of Table 2). The effects of assuming that these contaminants are either pure mucilage or pure pectin, instead of equal parts of the two, are respectively to decrease or increase the calculated heats of combustion of the 'pure' proteins by $c .0 .024 \mathrm{Cal} / \mathrm{g}$.

\section{DISCUSSION}

Earlier analytical work (Lugg \& Weller, 1944, 1948) has suggested that the preparations I $E, 2 E,{ }_{3} \mathrm{E}$ and ${ }_{4} \mathrm{E}$ of Lugg \& Weller (1944) are reasonably representative of the whole proteins in the leaves of the plants concerned, and that the amino-acid compositions of these preparations (on a $\mathrm{N}$ basis) are probably very similar. Certain physical properties of the native proteins, too, are known to be rather similar, and it seems likely, therefore, that the types of cross-linkages postulated as existing between polypeptide chains may follow similar patterns in the proteins. The heats of combustion of the pure protein moieties of the preparations might therefore be expected to be very close, and Table 2 indicates that this is indeed so.

The mean heat of combustion of the hypothetically 'pure' proteins is $5 \cdot 877 \mathrm{Cal}$./g. This value is near the upper limit of values obtained by Benedict \& Osborne (1907) for eighteen seed proteins, the values ranging from $5.35 \mathrm{I} \mathrm{Cal} / \mathrm{g}$. for wheat globulin to $5.908 \mathrm{Cal} . / \mathrm{g}$. for hordein (recalculated to our benzoic acid standard).

That the mucilage had an appreciably greater heat of combustion than the pectin is perhaps due to the fact that its molecule contains a considerable number of sugar, as well as uronic acid, residues; but the methylation of carboxyl groups could offset disparities in the heats of combustion of $-\mathrm{CH}_{2} \mathrm{OH}$ and $-\mathrm{COOH}$ units.

\section{SUMMARY}

I. The heats of combustion of reasonably representative protein preparations from leaves of Phalaris tuberosa, Hordeum murinum, Medicago sativa and $M$. denticulata have been measured. The values for the hypothetically 'pure' proteins were computed to be $5 \cdot 839,5 \cdot 882,5 \cdot 888$ and $5 \cdot 899$ Cal./g., respectively. 
2. The heats of combustion of linseed mucilage and citrus pectin have been measured, the computed values for the hypothetically 'pure' materials being 4 ' ror and $3.719 \mathrm{Cal} . / \mathrm{g}$. respectively.

We wish to thank Mr A. M. Gallacher for valuable assistance, and the Rosella Fruit Preserving Co. and Dr G. H. Josephs, California Fruit Growers' Exchange, for supply of, and information concerning, the commercial citrus pectin.

\title{
REFERENCES
}

Benedict, F. G. \& Osborne, T. B. (1907). \%. biol. Chem. 3, 119.

Jessup, R. S. \& Green, C. B. (1934). F. Res. nat. Bur. Stand., Wash., 13, 469.

Lugg, J. W. H. (1939). Protein Metabolism in the Plant. By A. C. Chibnall, Appendix I. New Haven:

Yale University Press.

Lugg, J. W. H. \& Weller, R. A. (1944). Biochem. Y. 38, 408.

Lugg, J. W. H. \& Weller, R. A. (1948). Biochem. F. 42, 408.

Lunge, G. \& Berl, E. (1921). Chemisch-technische Untersuchungen, 7th ed., 1, 430. Berlin: Julius Springer.

\section{The Digestibility and Absorption of the Calories, Proteins, Purines, Fat and Calcium in Wholemeal Wheaten-Bread}

\author{
By R. A. McCANCE and C. M. WALSHAM \\ Department of Experimental Medicine, University of Cambridge
}

(Received II November 1947)

Wheat is so important in human affairs that its digestibility has been investigated on many occasions. The literature was summarized and fresh experiments carried out by Borgström (1941), Macrae, Hutchinson, Irwin, Bacon \& McDougall (1942), Heupke (1943), McCance, Widdowson, Moran, Pringle \& Macrae (1945), Brull, Barac, Brakier-Zelkowiecz, Clemens, Crismer, Deltombe, Divry, Dubois, Dumont, DumontRuyters, Lambrechts, Neuprez, Nizet, Op de Beeck, Piersotte \& Thomas (1945) and by McCance \& Widdowson (1947). There are, however, matters still in dispute and aspects which have not been investigated, and the work now to be described was undertaken in an attempt to clarify some of the points at issue. The following seemed to be outstanding problems.

(r) Calories. Moran \& Pace (1942) rightly pointed out that the digestibility of wheat flour, in terms of energy, did not depend so much upon its percentage extraction as upon the amount of bran which it contained, and they suggested a method for assessing the digestibility of high-extraction flours from their fibre content. They took some data which had recently been obtained by Macrae et al. (1942) for the digestibility of $73 \%$ and wholemeal flours. They showed that the difference could be accounted for by supposing that every increase in fibre of $0.2 \%$ (over a basal figure of about $0.15 \%$ ) led to a decrease in digestibility of about $I \cdot I \%$. The possibilities of this 